\title{
Carried out laboratory tests and validation of the special type centrifugal pump
}

\author{
Badania doświadczalne i walidacja obliczeń numerycznych \\ pompy wirowej specjalnej
}

WITOLD LORENZ*

It has been presented the use of numerical simulations in the design process of special centrifugal pump (pitot tube pump) characterized by extremely low specific speed and nonstandard design. It has been shown the test rig, measurement methodology and the results of experimental tests. On this basis numerical model of the pump using ANSYS CFX software has been developed and validated.

KEYWORDS: centrifugal pumps, pitot tube pump, CFD simulations, validation of CFD results, ANSYS CFX

Zaprezentowano zastosowanie obliczeń numerycznych w procesie projektowania pompy wirowej specjalnej (pompy czerpakowej), charakteryzującej się skrajnie niskim wyróżnikiem szybkobieżności i niestandardową budową. Przedstawiono stanowisko, metodykę pomiaru i wyniki badań rzeczywistych. $\mathrm{Na}$ ich podstawie opracowano $i$ zwalidowano model numeryczny pompy za pomoca oprogramowania ANSYS CFX.

SŁOWA KLUCZOWE: pompa wirowa, pompa czerpakowa, obliczenia CFD, walidacja wyników CFD, ANSYS CFX

Pitot pumps, called otherwise as pitot tube pumps or pumps with rotating casing have been known on the industrial scale for about 50 years and they belong to the group of special type centrifugal pumps $[2,10,17]$. Their distinguishing feature is the ability to achieve high total head at the relatively small capacity from one stage, which characterize this type of pumps with such extremely low specific speed $n_{\mathrm{s}}=5.3[9,11,12,14]$. Specific, simple design and small weight cause that this pump enables highly reliable operation. The considered pump can be applied in energy industry, chemical industry: for pumping low-boiling factors, liquids without solid impurities and liquid metals such as mercury or gallium.

The original genesis of this survey was the increase of interest in these pumps by rockets and aircraft industry [2] and later they have been made attempts to install these pumps in micro CHP ORC systems of turbine cooling system [13].

The aim of the study was testing the existing pitot pump, development and validation of the CFD model targeted for increasing total head and better understanding of the physics phenomena occurring during the pump operation in the zone before the inlet of the pitot tube. The works were carried out thanks to two researches and development grants (research was carried out under European Social Found in the contest of Human Capital National Cohesion Strategy, agreement No. DGG/2080/09 and Grant-it-aid for scientific research form Ministry of Science and High Education - Faculty of Mechanical

* Dr inż. Witold Lorenz, CFD Engineer (w.lorenz@hv.pl) - R\&D Department, Hydro-Vacuum S.A. Grudziadz
DOI: 10.17814/mechanik.2016.10.450

Article awarded at the conference Simulation 2016

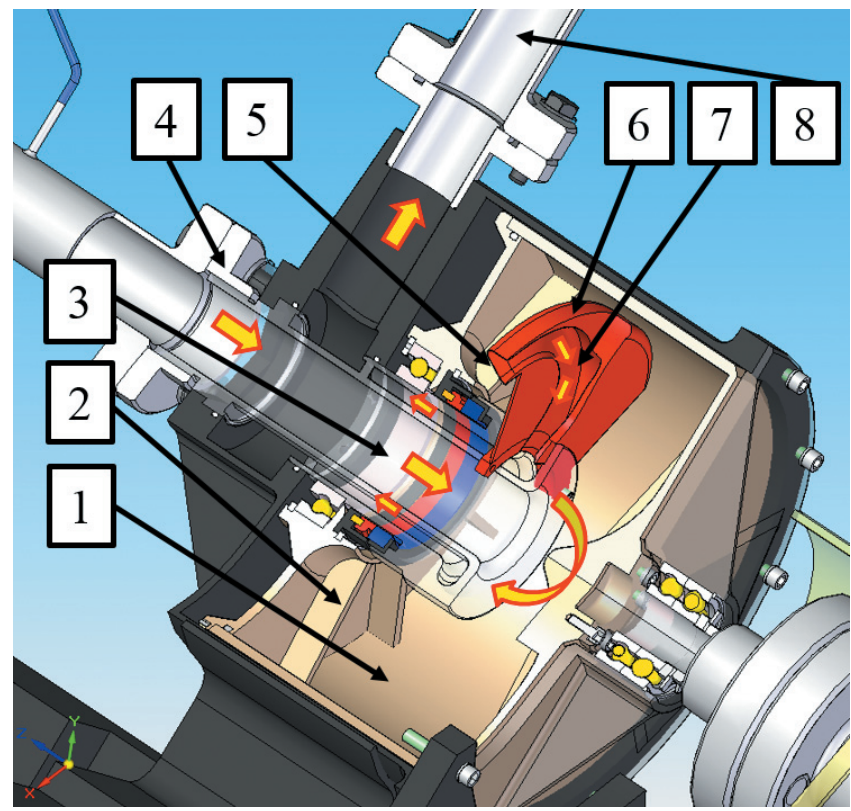

Fig. 1. Pitot tube pump, $n_{\mathrm{s}}=5.3$

and Power Engineering, Wroclaw University of Technology). The object of the study was the pitot tube pump designed and modernized in the Faculty Department of Flow Machinery (currently: Unit of Fundamentals of Design Engineering and Flow Machines) and produced in the former Pump Factory in Swidnica (currently: Group of Powen-Wafapomp SA) with nominal performance: capacity $Q_{\text {nom }}=15 \mathrm{~m}^{3} / \mathrm{h}$, total head $H_{\text {nom }}=144 \mathrm{~m}$ at rotation speed $n_{\text {nom }}=2960 \mathrm{rpm}$. The construction and operation of the pump is shown at Fig. 1.

Due to the casing rotation (1) with bladed side walls (2) it is caused a rotodynamic motion of the liquid which flows inside the rotating casing through the internal inlet pipe (3) with fixed suction flange (4). Liquid, spinning in a closed volume flows through sectional inlet (5) into the fixed pitot tube (6). Then, through the diffuser internal channel (7), of the pitot tube (6) it flows to the discharge pipe (8) and it is finally discharged to the piping system. Dependencies describing the achieved energy performances are presented in detail in [12].

\section{Experimental tests}

In order to determine the pump's performances, it were carried out laboratory tests and determined characteristic curves. Measurements, test rig and analysis of measurement errors were performed according to [15] Class 2, taking into account [16]. The pumped medium: clean tap 


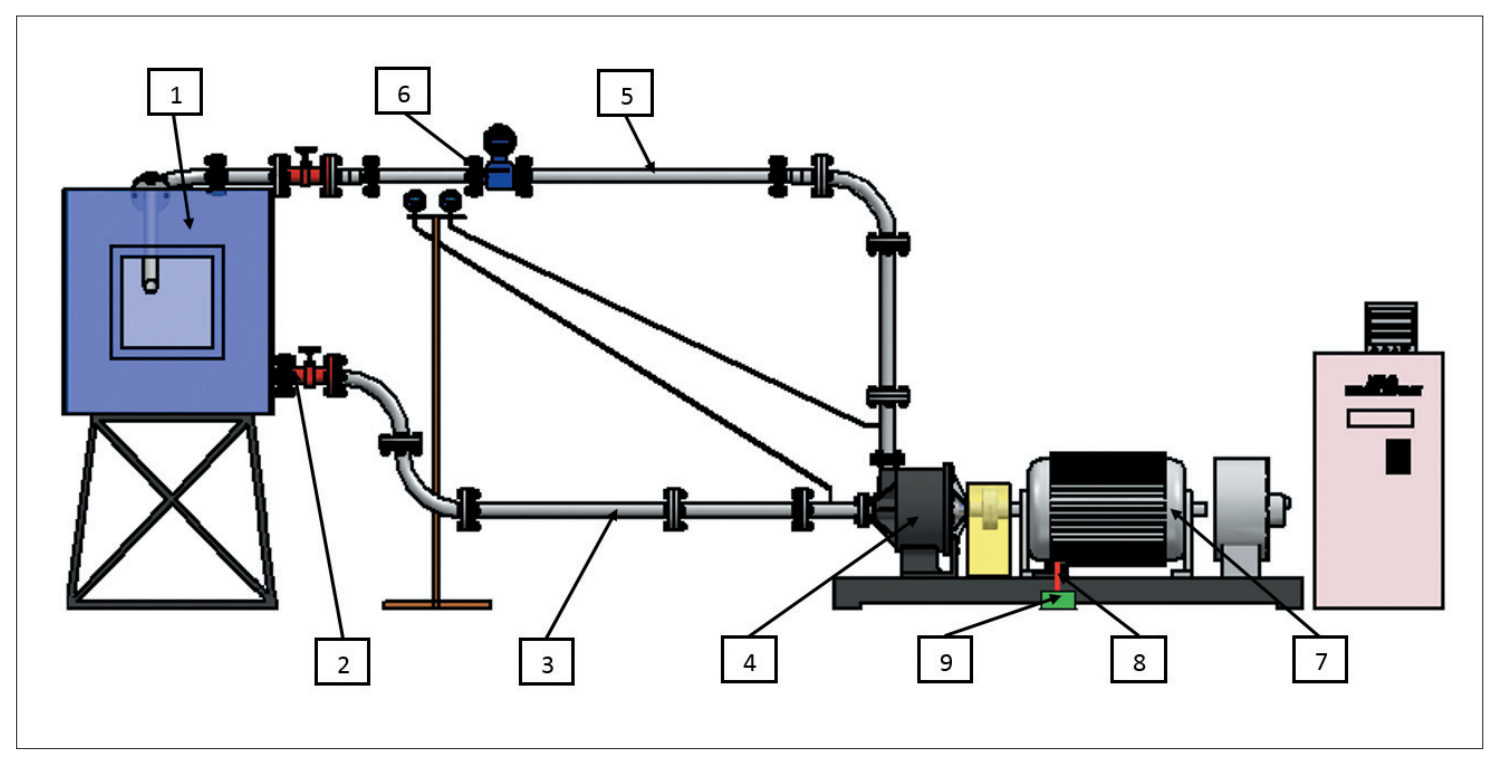

water at a temperature approx. $20^{\circ} \mathrm{C}$ was pumped into closed system. The liquid flowing out from the tank (1, Fig. 2), flows through the valve (2), elbows and straight section (3) to the pump (4). As a result of the work of the examined pumping unit water was discharged by discharge pipe line (5) with fitted flow meter (6) to the tank (1). Measurement of static pressure was executed thanks to flanges placed on the suction (3) and discharge pipe lines (5). Cradle positioning of the electric motor (7) enabled the direct measurement of the torque on the pump's shaft, which was measured as the force of arm pressure (8) with known weight on laboratory scales (9).

Instruments were chosen in relation to the measuring range in the following class: electromagnetic flow meter and pressure transducers class 0.2, photoelectric meter and thermometer class 0.5 , barometer class 1.0. The scheme of test rig is shown in Fig. 2.

The achieved characteristic curves with marked bars of measurement errors are shown in Fig. 3 and they were basis for the development of the numerical model of the pump.

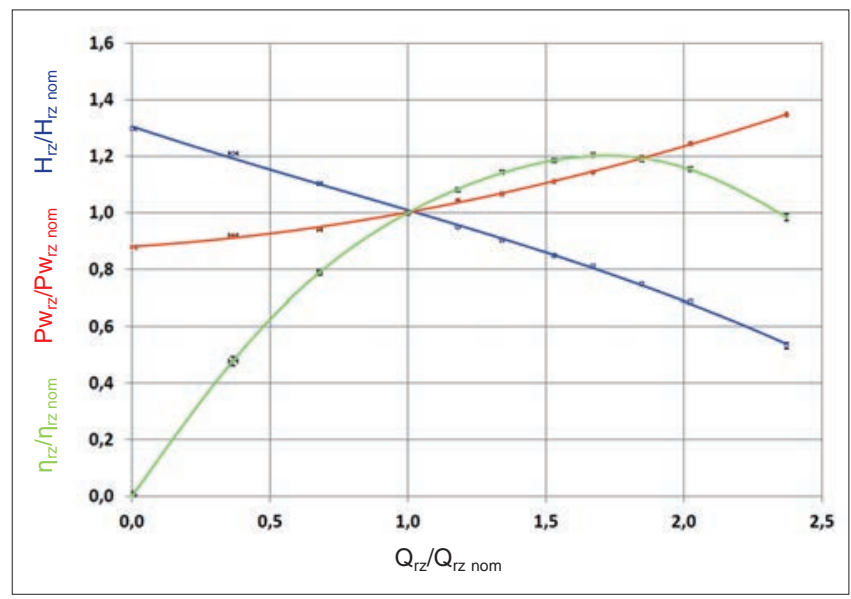

Fig. 3. Characteristic curves of the pitot tube pump

\section{Numerical simulations}

To carry out the CFD simulations it was used commercial software ANSYS Inc. (ANSYS Academic Research CFD, HPC) taken from resources of Wroclaw University of Technology and WCSS (calculations have been carried out using resources provided by Wroclaw Centre for Networking and Supercomputing, http://wcss.pl, grant No. 251).

3D CAD models of considered geometries (suction pipe with pitot tube and rotating casing - Fig. $5 \mathrm{a}$ and internal channel - Fig. 5b) were discretized by finite volume method [18] with using the commercial software ANSYS ICEM CFD [4]. In all cases it was used the smallest and most accurate for executing calculations tetragonal mesh with prismatic elements located at the walls without significant gradients of cell size (increasing the cell size: $\Delta x \leq 1,2$ ). The number of layers of prismatic elements for each model was selected individually. The mesh size of the interfaces was constant and way of their locations are non-matching. The number of elements of discrete model's mesh was about 10-12 million.

Numerical calculations were solved using calculation code ANSYS CFX [3]. It was chosen solver RANS type with linear eddy viscosity models for the turbulence. ANSYS CFX is a cell-vertex (variables are stored at the vertices of the mesh elements), finite volume, fully coupled, implicit solver (technology came originally from TASCFlow [1]) and so the pressure-velocity coupling is inherent in the solution procedure. Pressure and velocity are co-located, therefore pressure-velocity decoupling is dealt with using Rhie-Chow approach. Solver has all three momentum equations with the pressure equation in the same matrix therefore they are solved together. Coupled solvers take more time per iteration and use more memory as the matrix is bigger, but coupled solvers usually converge much faster as you only converge on the non-linear terms [19].

For all equations it was used discretization scheme: High Resolution, which keeps the solution as close to $2^{\text {nd }}$ order as possible without going unbounded. Modelling of flow in the pitot pump takes into account the narrow gap between the back of the pitot tube and the roller surface of the rotating casing. Therefore, it was applied the model based on the Boussinesq's hipotesis, k- $\omega$ SST (Shear Stress Transport) [7]. This model was proposed by Menter in 1994 and it was invented due to modification of models $k-e$ and $k-\omega$. Flows on the boundary layer are mapped as using $k-\omega$, and the flows inside the model as k-e [5]. The design and operation scheme of the model is presented on Fig. 4. In the Menter SST model, the transport equations for the turbulent kinetic energy $k$ and the specific 


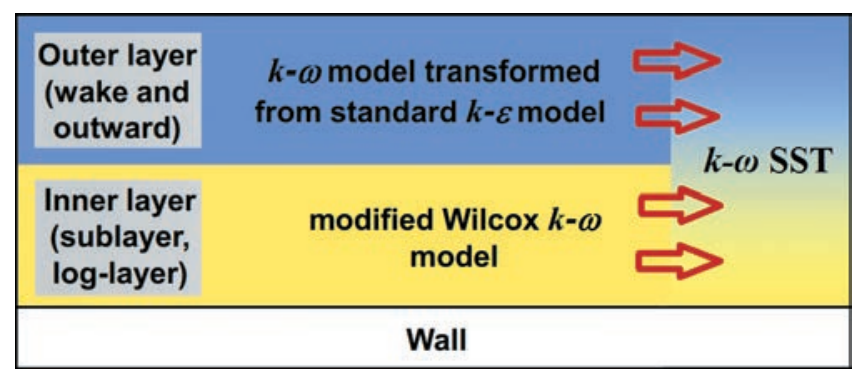

Fig. 4. Operation scheme of k-w SST turbulence model [5]

dissipation rate $\omega$ is expressed at positions (1) and (2), which are described in detail [6]:

$$
\begin{gathered}
\rho \frac{\partial k}{\partial t}+\rho u^{i} \frac{\partial k}{\partial x^{i}}=\frac{\partial}{\partial x^{j}}\left(\left(\mu+\frac{\mu_{t}}{\sigma_{k}}\right) \frac{\partial k}{\partial x^{j}}\right)+G_{k}-Y_{k} \\
\rho \frac{\partial \omega}{\partial t}+\rho u^{i} \frac{\partial \omega}{\partial x^{i}}=\frac{\partial}{\partial x^{j}}\left(\left(\mu+\frac{\mu_{t}}{\sigma_{\theta}}\right) \frac{\partial \omega}{\partial x^{j}}\right)+G_{\omega}-Y_{(0)}+D_{\omega}
\end{gathered}
$$

At the inlet side it was given velocity inlet (green field, Fig. 5) boundary condition, which enables the transport of fluid in both directions: inflow and outflow. Turbulence at the inlet was 0,05. At the outlet side it was also given bidirectional boundary condition: pressure opening (red field). Walls which were rotating in the model (blue fields) were given rotation speed in accordance with the rotational speed of the rotating casing of real pump. The remaining walls (silver color) were not given any rotation. Furthermore, for all walls Dirichlet and Neumann type boundary con-

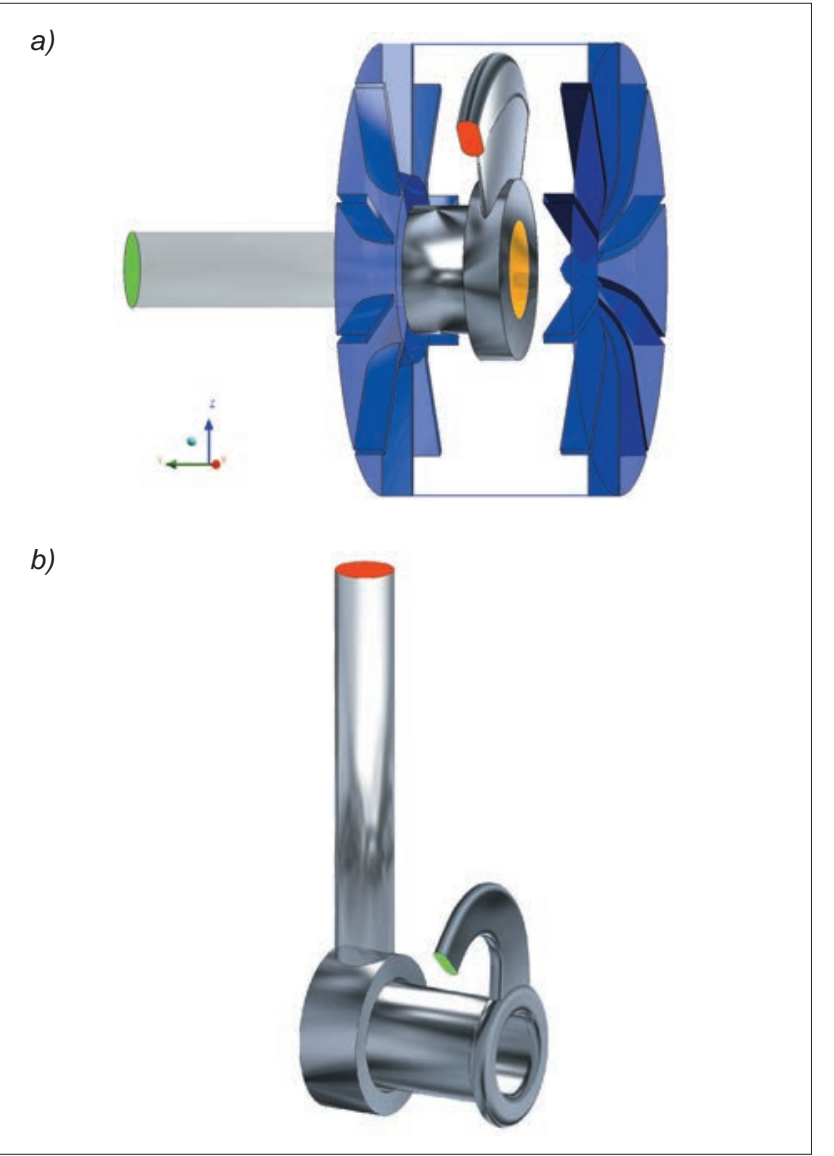

Fig. 5. Discrete model of the pitot tube pump: a) suction pipe with pitot tube and rotating casing, $b$ ) internal channel dition were implemented. Steady State flow simulations were performed. Interfaces were combined thanks to GGI model - Frozen Rotor (orange field). During conducting of calculations there haven't been used any algorithms to adapt the mesh.

\section{The results of numerical simulations}

Based on the results of numerical simulations it has been prepared dimensionless characteristics curves: for total head $H$ and pressure loss hst of inner channel as a function capacity $Q$ (Fig. 6).

In the most important performance range $Q / Q_{\text {nom }}=$ $=(0.8-1.2)$ the discrepancy of obtained results from the numerical calculations and experimental tests does not exceed $5 \%$. Due to the low value of $n_{\mathrm{s}}$, the deviation is relatively small. In the literature [8] there were given limit deviations between the results obtained with experimental and numerical simulations: for $n_{\mathrm{s}} \geq 24$ these discrepancies are $1-3 \%$, whereas for $n_{\mathrm{s}} \leq 24$ the authors do not provide unequivocal values. For $n_{\mathrm{s}} \leq 10$ after analysing the nature of the average curve of errors, discrepancies may be 10-12\% [8].

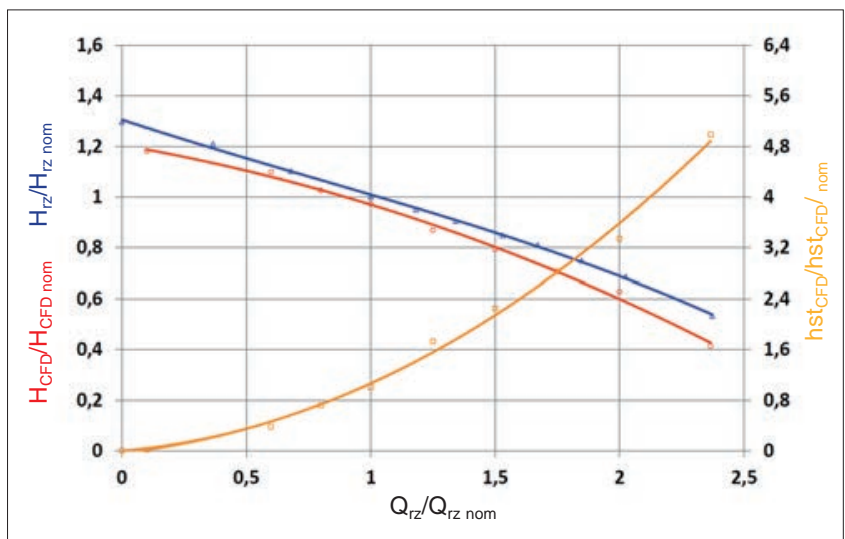

Fig. 6. Head/discharge and losses/discharge curves of the pitot pump

All qualitative results of are presented for $Q / Q_{\text {nom }}=1$. In the inlet section to the diffuser channel of the pitot tube (Fig. 7) it is shown the total pressure field which, because of the nature of the liquid flow can be conventionally divided into three similar sized sub-areas. The highest pressure of the pitot's tube inlet is about $P_{\mathrm{INL}}=2.3 \mathrm{MPa}$ (average arithmetic from the surface marked as $P_{\mathrm{INL}}$ ) is obtained from the area located in $1 / 3$ of the height from the back of the pitot tube (at 1/3 A). In the central part the pressure decreases significantly and its average value

Fig. 7. Total pressure fields on the inlet side of the pitot tube

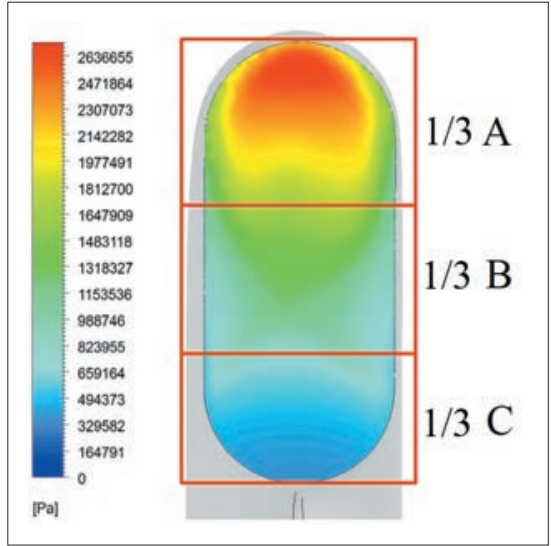




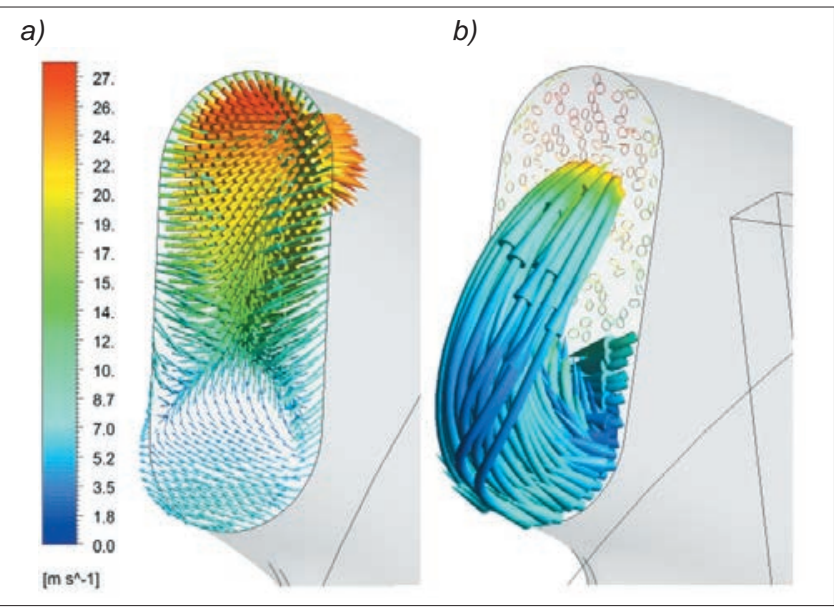

Fig. 8. The vectors of the relative velocity (a) and the track of the liquid particles flowing out from the inlet's pitot tube $(b)$ tube back (Fig. 9b) to which the liquid flows nearby the pitot's tube inlet bladed side walls.

\section{Summary}

The developed numerical model shows good compatibility with the results obtained on the basis of experimental tests.

Thanks to using different shapes of the pitot tube and its inlet it has been developed numerical model which allows to predict the performance on stage CAD modelling and CAE analysis. You should be aware, that the result of CFD analysis is approximate and dictated by the simplification function and variable settings of discrete model. CFD modelling creates the possibility of eliminating decision errors in the design process at the relatively low cost and time designated to development of solutions for implementation.

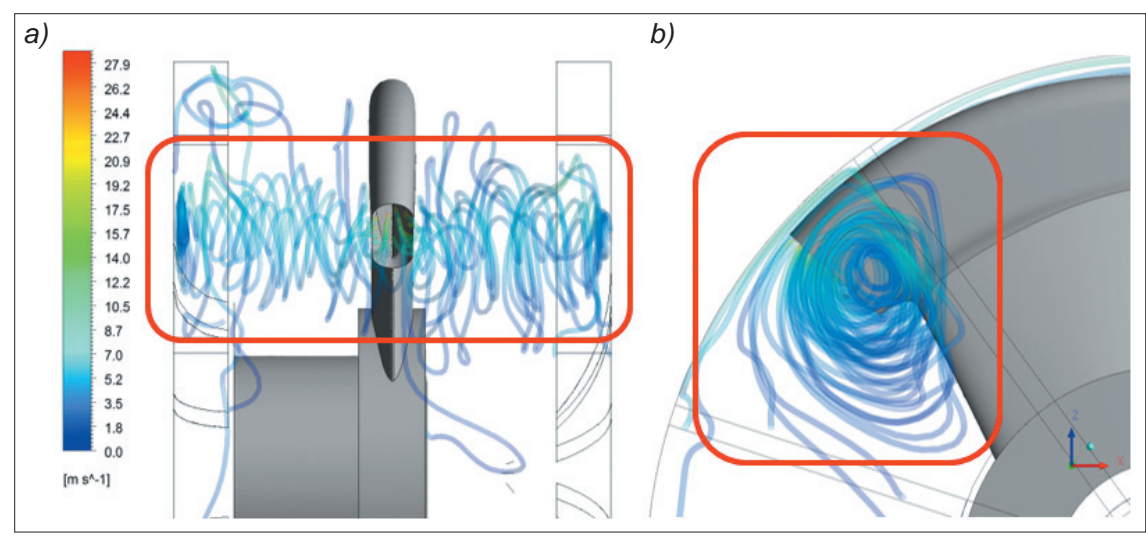

Fig. 9. The spiral trajectories in the pitot tube pump: a) front view, $b$ ) side view

\section{REFERENCES}

1. Anciger D., Jung A., Aschenbrenner T. "Prediction of rotating stall and cavitation inception in pump turbines". IOP Conf. Series: Earth and Environmental Science. 25th IAHR Symposium on Hydraulic Machinery and Systems. Vol. 12, No. 1 (2010), 012013.

2. Angle T., Turner M. "The Weir VSR $2100-$ a new concept in high-pressure pumping". The Institution of Mechanical Engineers. $2^{\text {nd }}$ International Symposium on Centrifugal Pumps (The state of the art and new developments S966/007/2004), 2004.

3. ANSYS Inc. ANSYS documentation for $R$ 11.0. Canonsburg, ANSYS Inc., 2007.

4. ANSYS Inc. ANSYS ICEM CFD User's Guide. Canonsburg, ANSYS Inc., 2007.

5. ANSYS Inc. Turbulence Modeling Using ANSYS Fluent. R 14.5, 2013.

is $P_{\mathrm{INL}}=1.4 \mathrm{MPa}(1 / 3 \mathrm{~B})$. The lower part generates the lowest pressure, i.e. $P_{\mathrm{INL}}=0.5 \mathrm{MPa}(1 / 3 \mathrm{C})$. The average arithmetic pressure on the inlet surface of the pitot tube is $P_{\text {INL }}=1.8 \mathrm{MPa}$. The reason for this division is the distribution of vectors of relative velocity in this section. The liquid flowing out from the upper part of the pitot tube (1/3 A) has the highest kinetic energy, therefore it creates the highest pressure. In the upper part of the inlet the average relative velocity reaches $w=25.0 \mathrm{~m} / \mathrm{s}$. In the central $(1 / 3 \mathrm{~B})$ and lower field $(1 / 3 \mathrm{C})$ the average velocity is respectively $w=13.5 \mathrm{~m} / \mathrm{s}$, and $w=3.5 \mathrm{~m} / \mathrm{s}$ (Fig. $8 a$ ).

The most noteworthy thing is the occurrence of reverse fluid flow in the middle and the bottom part of the inlet (Fig. 8b). The liquid flows from the upper part of the inlet into the internal channel of the $(1 / 3 \mathrm{~A})$, then some liquid amount changes direction and flows into the center (1/3 B) and the lower part of the inlet $(1 / 3 \mathrm{C})$ and flowing out from the inlet, whereupon it flows once again through field $1 / 3 \mathrm{~A}$ and $1 / 3 \mathrm{~B}$. Developing reverse flow does not improve the energy parameters, but is a generator of significant losses and pressure gradients between the different parts of the inlet. For $Q / Q_{\text {nom }}=1$ the fluid flows into the channel of the pitot tube through surface which is only approx. $58 \%$ of the total inlet area. The remaining part of the inlet is supplied by spiral vortex, located at the entire width of the rotating casing (Fig. 9a) and on the lower part of the pitot
6. Bates P., Lane St., Ferguson R. "Computational Fluid Dynamics". West Sussex: Wiley, 2005.

7. Blazek J. "Computational Fluid Dynamics: Principles And Applications". Elsevier, 2001.

8. Gülich J. F.“Centrifugal pump”. Berlin: Springer-Verlag Berlin Heidelberg, 2008.

9. Jędral W. "Pompy wirowe". Warszawa: Oficyna Wydawnicza Politechniki Warszawskiej, 2014.

10. Lorenz W., Plutecki J. „Wpływ kształtu wlotu czerpaka na wysokość podnoszenia pompy z wirującym bębnem”. Górnictwo Odkrywkowe. R. 51, nr 4 (2010): s. 33-39.

11. Lorenz W., Janczak M. "Sukcesy i niepowodzenia w modelowaniu przepływu cieczy w pompach wielostopniowych o małym wyróżniku szybkobieżności”. Mechanik. R. 97, nr 3 (2016): s. 141-145.

12. Lorenz W. „Modelowanie elementów odprowadzenia cieczy pompy czerpakowej". Rozprawa doktorska, Wydział Mechaniczno-Energetyczny Politechniki Wrocławskiej, 2011.

13. Mikielewicz J., Kaniecki M. „Modelowe kompleksy agroenergetyczne jako przykład kogeneracji rozproszonej opartej na lokalnych i odnawialnych źródłach energii. Badania eksperymentalne, prace projektowe i obliczenia numeryczne pompy obiegowej mikrosiłowni na czynnik niskowrzący". Nr POIG.01.01.02-00-016/08. Gdańsk, 2011.

14. Osborn S. "The Roto-Jet pump: 25 years new". World Pumps. Vol. 1996, Iss. 363 (1996): pp. 32-36.

15. Standards catalogue, "Rotodynamic pumps - Hydraulic performance acceptance test - Grades 1 and 2". PN-EN ISO 9906:2002.

16. Standards catalogue, "Rotodynamic pumps and pumping systems - Parameters, Terminology, Definitions, Symbols and units". PN-M44001:1981.

17. Snasskij K. „Novye nasosy dla małych podač $i$ vysokich naporov”. Moskva: Mašinostrojenie, 1973.

18. Tu J., Yeoh G.H., Liu C. "Computational Fluid Dynamics". Elsevier Inc., 2008.

19. www.cfd.online.com (dostęp: 01.06.2016 r.).

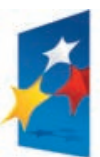

HUMAN CAPITAL NATIONAL COHESION STRATEGY

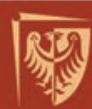

Wrocław University of Technology
EUROPEAN UNION EUROPEAN SOCIAL FUND

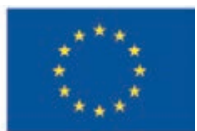

